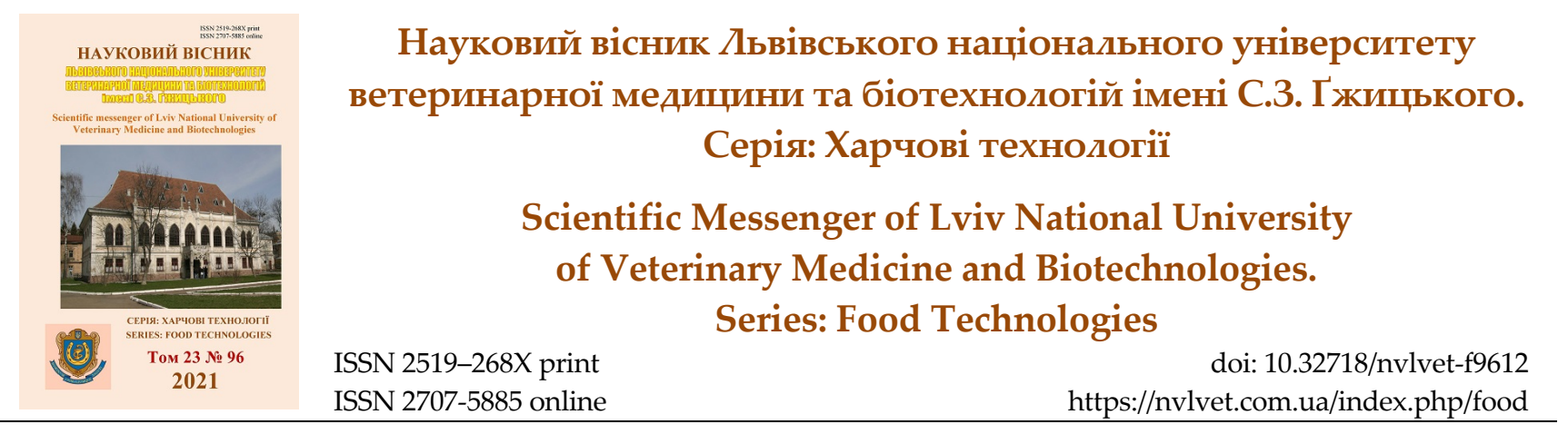

UDC 515.2

\title{
Kinematic projection in modern technologies
}

\author{
I. G. Svidrak, I. S. Aftanaziv, O. I. Strogan, A. O. Shevchuk \\ Lviv Polytechnic National University, Lviv, Ukraine
}

Article info

Received 20.05.2021

Received in revised form 21.06.2021

Accepted 22.06.2021

National University "Lviv Polytechnic", S. Bandera Str., 12, Lviv, 790013, Ukraine.

Tel.: +38-066-229-50-87 E-mail: svidrak99@gmail.com
Svidrak, I. G., Aftanaziv, I. S., Strogan, O. I., \& Shevchuk, A. O. (2021). Kinematic projection in modern technologies. Scientific Messenger of Lviv National University of Veterinary Medicine and Biotechnologies. Series: Food Technologies, 23(96), 67-75. doi: 10.32718/nvlvet-f9612

The trajectories and coordinates of unmanned aircrafts spatial location determination is researched with the help of kinematic projection means. The methodology offered below considers the formation of two mobile and independent kinematic projection centers raised into the air by drones. The electromagnetic radio waves emitted by them, penetrating an unknown aircraft object, form two independent projecting rays intersecting at the searched aircraft location point. In this case, the searched object spatial location instantaneous (at a certain point in time) point will be placed on an imaginary "picture plane" on a line connecting the points projections generated by drones interceptors projecting rays. As far as all of the projection objects in this case are movable, all the moving trajectory projection of the searched aircraft will be displayed on the monitor. The introduction of another "picture plane", perpendicular to the main one, will help to build an axonometric mapping not only for projections, but also for the aircraft spatial movement trajectory itself. Each point of this trajectory gives an information about the "instantaneous" coordinates of the aircraft spatial location. The method of application of kinematic projection for display of a trajectory of movement and search of coordinates of moving objects is described. In kinematic projection, all its key components, namely the object, the center of projection, the image plane and the projecting rays, are in continuous motion with certain speeds and accelerations. Kinematic projection deepens the field of practical application of descriptive geometry. This is confirmed by the example of practical application of kinematic projection presented in the article for improvement of remote control of tillage equipment in automated land treatment complexes. The main technical support for the practical application of kinematic projection are stationary radio towers or unmanned aerial vehicles (BPLA), such as drones. They are equipped with video cameras and electromagnetic radiation devices. This equipment serves as a center of kinematic projection. The projecting rays generated by the projection center will be received by a stationary command post (center). It is equipped with a radar system (radar) and modern computer equipment with appropriate software. This equipment, in this case, performs the function of a "picture plane", which will reflect the trajectory of agricultural machinery. Actuators and controls of the movement of tillage equipment are equipped with receivers of control radio waves and means of automated control. The use of kinematic projection helps to improve the quality of tillage. This is ensured by the fact that its use is carried out automatically and eliminates possible errors of operators. Kinematic projection can also be used in military affairs to detect enemy drones in the airspace. In this case, use a kind of kinematic projection with its two centers of generation of projecting rays. This is an example of the solution of the so-called "inverse problem" of kinematic projection, which provides the ability to search for the coordinates of the motion of the projected object at a known trajectory of its motion. The main advantage of kinematic projection is the ability to identify and display an object on a computer screen not only in a flat view, but also taking into account its spatial coordinates.

Key words: unmanned aircraft, drone, movement trajectory, kinematic projection, projection moving center, trajectory projection, projecting ray, operator, software.

\section{Кінематичне проеціювання в сучасних технологіях}

\author{
І. Г. Свідрак, І. С. Афтаназів, О. І. Строган, А. О. Шевчук
}

Національний університет “Львівська політехніка”, м. Львів, Украӥна 
Розглянуто визначення траєкторій руху та координат просторового розташування безпілотних літальних апаратів (БПЛА) засобами кінематичного проеціювання. Запропонована методика передбачає формування піднятими у повітряний простір дронами-перехоплювачами двох рухомих і незалежних центрів кінематичного проекціювання. Випромінювані ними електромагнітні радіохвилі, пронизуючи невідомий літальний об'єкт, формують два незалежних проектуючих промені, шео перетинаються між собою в точичі розташування розшукуваного літального апарату. При цььому миттєва (на певний момент часу $\Delta$ ) проекція точки просторового розташування розшукуваного об'єкту розміститься на уявній «картинній площині» на лінії, шуо з'єднує між собою проекиії точок генерованих дронами-перехоплювачами проектуючих променів. Оскільки всі об'єкти проеціювання у даному випадку є рухомими, на екрані монітора оператора відобразиться вся проекція траекторії руху розшукуваного об'єкту. Запровадження ще однієї “картинної площини”, перпендикулярної до основної, дозволить побудувати аксонометричне відображення не тільки проекиій, а й безпосередньо самої траєкторії просторових переміщень літального апарату. Кожна точка ичєї траєкторії надає інформацію про “миттєві” координати просторового розташування літального апарату. Досліджено методику застосування кінематичного проеціювання для відображення траєкторї руху та пошуку координат рухомих об'єктів. 3'ясовано, щио специфікою кінематичного проеціювання є те, щзо всі ї̈ ключові складові, а саме - об'єкт, центр проеціювання, картинна площина та проектуючі промені, знаходяться у неперервному русі із певними швидкостями та пришвидщеннями. Така специфічна особливість кінематичного проеціювання не тільки істотно розиирює технологічні можливості нарисної геометрї як науки про графічне відображення просторових об'єктів, а й істотно поглиблює галузі практичного іі застосування. Встановлено, щзо підтвердженням ицьому є розглянуті у даній роботі приклади практичного застосування специфіки кінематичного проеціювання для вдосконалення дистаниійного керування землеобробною технікою в автоматизованих комплексах управління. 3'ясовано, щчо ие дає змогу усувати негативний вплив «людських чинників» операторів, щзо відстежують траєкторії переміщень техніки оброблюваною земельною ділянкою. Досліджено, шьо основні складові технічного забезпечення практичного застосування кінематичного проеціювання для відстежування переміщень землеобробної техніки й різних транспортних засобів полягає в оснащені відеокамерами та приладами електромагнітного випромінювання стаціонарні радіовежі або безпілотні літальні апарати (БПЛА), наприклад, дрони, щзо виконуватимуть функиї центрів кінематичного проеціювання. Рекомендовано, цуо сприймання генерованих иентром проеціювання проектуючих променів тут може бути покладено на оснащений радіолокаційною системою (РЛС) та сучасним комп'ютерним спорядженням із відповідним програмним забезпеченням стаціонарний командний пункт (центр). Це устаткування, у даному випадку, виконуватиме функцію “картинної площини”, на якій відображатиметься траєкторія руху землеобробної техніки. 3'ясовано, щзо виконавчі механізми та органи управління рухом землеобробної техніки у цьому випадку доречно оснастити приймаючими керуючі радіохвилі пристроями та засобами автоматизованого управління. Представлено, щзо окрім відстежування траєкторії рухів об 'єктів на земній поверхні кінематичне проеціювання може застосовуватися й у військовій справі для виявлення ворожих безпілотних об 'єктів у повітряному просторі. У ц̧ьому випадку використовують різновид кінематичного проеціювання із двома його иентрами генерування проектуючих променів.

Ключові слова: безпілотний літальний апарат, дрон, траєкторія руху, координати, кінематичне проеціювання, рухомий центр проеціювання, проекція траєкторії, проектуючий промінь, оператор, програмне забезпечення.

\section{Ветуп}

Розвиток впродовж останніх десятиліть космічної техніки, засобів зв'язку та комунікацій, комп'ютерних мереж тощо неодмінно мали зумовити формування i постановку нових задач та проблематик перед інженерною наукою. Зокрема i як щодо спроможностей забезпечення не лише підвищених швидкостей просторових переміщень різноманітних об'єктів, а і стосовно теоретичного опису та відображення координатної прив'язки рухомих об'єктів та засобів контролю їхнього стану і переміщень. Проблематика потреби невпинного контролю за рухомими об' єктами сприяла не лише стрімкому розвитку сучасних технічних засобів радіозв'язку та передачі інформації, а й певною мірою дотичних до опису рухомих об'єктів наук, зокрема аерофотогеодезії, оптичної фізики, певних напрямів математики, покликаних теоретично описати і обгрунтувати закономірності їх руху (Bespalov et al., 2020; Shevchyk et al., 2021).

Торкнулась ця проблематика і такої складової математичної науки як нарисна геометрія. Зокрема перед нарисною геометрією як наукою геометричного відображення взаєморозташування елементів простору постало завдання створення теорії кінематичного відображення. Під кінематичним відображенням слід розуміти проеціювання, при якому всі його елементи, а саме центр проеціювання, фокальні фігури проеціюючих комплексів і конгруенцій, об'єкт проеціювання (прообраз) та носій проекцій (“картинна площина”) можуть здійснювати взаємонезалежні просторові переміщення у просторі й часі.

Одним із перших фундаментальних досліджень в галузі кінематичних проблем графічних відображень можна вважати опубліковану в 1936 році роботу M. А. Риніна "Кіноперспектива" (Rynin, 1936). У даній роботі розглянуті деформації кінозображення рухомих предметів. Тут же досліджена і зворотна задача - визначено складові руху об'єкта за його кінематографічним відображенням. Описано також певні часткові випадки руху оригіналу, зокрема прямолінійні, що перпендикулярні “картинній площині”, а також обертові.

Дослідженнями Л. М. Ліхачова, що відображені в роботах (Lihachev, 1975), було систематизовано попередній досвід кінематичного проеціювання. У його опублікованій в 1975 р. монографії "Кіноперспектива” досліджено проблематику реконструювання просторових форм і траєкторій руху об'єкту, методи визначення швидкостей і прискорень тощо. В основу запропонованої Л. М. Ліхачовим кіноперспективи покладено запроваджене ним поняття "кванта руху", під яким розуміється певна абстрактна величина миттєвого просторового переміщення точки за інтервал часу $t$.

$$
\Delta S=\Delta x+\Delta y+\Delta z
$$

Квант руху фігури визначається системою квантів руху окремих іï точок. Після цього розглядаються перспективні зображення квантів руху відрізків i площин, що названі автором квантограмами, та проводиться їх реконструкція і аналіз. 
Роботи О. К. Кульмінського (Kul'minskij \& Nikolaevskij, 1971) присвячено проблематиці кіноперспективи та кіноаксонометрії як методу об'ємнографічного моделювання. Тут же розглядається і перспектива застосування кіноаксонометрії до проектування автомобільних шляхів.

У дослідженнях В. Є. Михайленко і М. В. Ковтун (Mihajlenko et al., 1972) розглядається проектування так званим “пласким" жмутком, що переміщається у вертикальному напрямку. У цьому випадку кінематичні “щільові” фотографування дозволяють усунути традиційне проеціювання із декількох центрів і притаманне йому “змазування” зображення на картинній площині. Картинна основа тут зазвичай перпендикулярна траєкторії руху центра. У статті розглянуто проеціювання лінійних і нелінійних (2-го порядку) об’єктів та реконструкція прообразів за власними та відкинутими тінями.

У роботі Д. І. Ткач (Tkach, 1968) досліджено центрове рухоме проеціювання, в якому траєкторія центру проектування прямолінійна і перпендикулярна до площини проекцій, а прообрази нерухомі. Тут встановлено існування простору-проекції, який перебуває в перспективному зв'язку із простором-оригіналом, i бієктивна відповідність між цими просторами.

У опублікованій в 1991p. роботі (Pilipaka, 1991) автора С. Ф. Пилипака подано алгоритмічний опис послідовності визначення точок твердого тіла, що переміщається по просторовій криволінійній траєктоpiї з допомогою проеціювання із нерухомого центра на рухому площину.

Вагомий внесок у становлення та розвиток кінематичного проеціювання привнесено науковцями НУ "Львівська політехніка" В. М. Глоговським та I. Г. Пулькевич. У їніх роботах (Kalinovskaja et al., 1994; Pulkevych, 1994) вперше було запропоновано використання розроблених ними лінійних операторів для грамографічних, ротографічних та спірографічних відображень рухомих об'єктів простору.

Поряд зі створенням алгоритмів рішень прямої задачі кінематичного проеціювання для пошуку проекцій траєкторій просторових переміщень об'єктів авторами (Kalynovska et al., 1994) було розроблено i грунтовно досліджено також і алгоритми рішення оберненої задачі. Обернена задача передбачає пошук за відомими траєкторією руху координат просторового розташування об'єкта.

Таким чином, варто відзначити, що науковцямигеометрами усвідомлена проблематика та потреба у переході від вже доволі досконало вивченого статичного проеціювання до кінематичного.

Мета і методи дослідження - розробка принципових схем та алгоритмів рішення і застосування прямої та оберненої задач кінематичного проеціювання. Також до завдань дослідження належало: створення алгоритму побудови проекцій траєкторій просторових переміщень об'єктів кінематичного проеціювання; розробка принципової схеми вдосконаленого методикою кінематичного проеціювання автоматизованого землеобробного комплексу; розробка методик використання алгоритму рішення “оберненої задачі" кінематичного проеціювання для пошуку в повітрі та товщі води рухомих об'єктів.

\section{Матеріал і методи досліджень}

Дослідження кінематичних проекційних відображень доцільно почати з розгляду лінійних операторів. Зокрема, для систематизації сполучення основних видів руху, що розглядаються в даній роботі, потрібно дослідити грамографічне відображення - відображення, при якому всі елементи проекційного апарату здійснюють прямолінійні рухи (рис. 1).

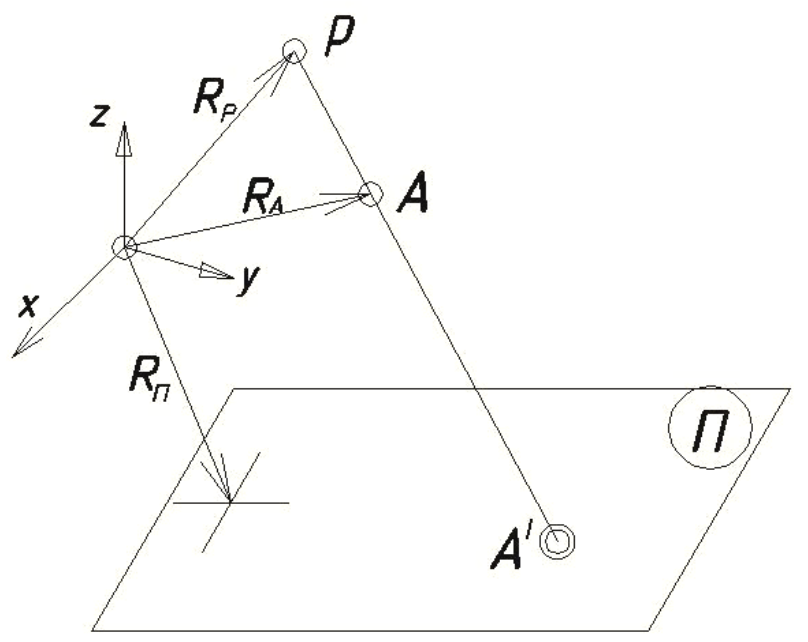

Рис. 1. Принципова схема грамографічного відображення проекцій точки при центровому кінематичному проеціюванні

Умовно кінематичні відображення лінійними операторами позначають

$$
F: A_{j} \frac{P_{i}}{(\ldots)} \rightarrow A_{j}(j=1,2, \ldots) .
$$

При цьому прийнято до уваги, що проеціювання здійснюється при одночасних та взаємоназалежних рухах всіх елементів відображення (прообразу $A$, центру проекціювання $P$ і носія образів $\pi$ )

$$
r_{a}: A_{j}=A_{j}(t) ; \quad r_{p}: P_{j}=P_{j}(t) ; \quad r_{\pi}: \pi_{j}=\pi_{j}(t) .
$$

(...) - в дужках позначаються види рухів: $\gamma$ - прямолінійний, $\rho$ - обертовий, $\sigma$ - гвинтовий.

Графічне відображення лінійними операторами здійснюється за допомогою вироджених комплексів нульової кривини, зокрема центровим проекціюванням за таким алгоритмом.

$$
\begin{gathered}
F: A_{j} \frac{P_{i}}{(\ldots)} \rightarrow A^{\prime}{ }_{j}(j=1,2, \ldots) . \\
r_{a}: A_{j}=A_{j}(t) ; \quad r_{p}: P_{j}=P_{j}(t) ; \quad r_{\pi}: \pi_{j}=\pi_{j}(t) . \\
P_{j} \cup A_{j}=S_{j} \\
S_{j} \cap \pi_{j}=A_{j}^{\prime} \\
\left\{A_{j}^{\prime}\right\} \supset A_{1}^{\prime}, A_{2}^{\prime}, \ldots
\end{gathered}
$$

Будемо вважати, що між кінематичними режимами руху (швидкість, прискорення) точки та центру проекціювання і порядком променевої проекціюючої 
поверхні виведені та досліджені рівняння первинних та вторинних проекцій траєкторій прообразу $A$ при: рівномірному русі $A$ та рівнозмінному русі центру проекціювання $P$; рівномірному русі $A$ і $P$ в спеціалізованому положенні, коли $A_{0}\left(x_{01}, 0, Z_{01}\right)$, $P_{0}\left(x_{02}, y_{02}, 0\right)$. На основі виведених рівнянь необхідно визначити види траєкторій прообразу рухомого обєкту.

Нехай $f_{1}\left(y=y_{1} ; z=k_{z} ; x=b_{z}\right)$ i $f_{2}\left(x=x_{2} ; z=z_{2}\right)$ прямолінійні траєкторії руху відповідно до прообразу (точки) $A$ і центру проекціювання $P$, які починають одночасно рухатись: точка $A-$ рівномірно зі швидкістю $v_{0}$ і прискоренням $a$ (рис. 2).

Задані умови руху виділяють із лінійчатої конгруенції $s^{2}\left(f_{1} ; f_{2}\right)$ з фокальними фігурами $f_{l}$ i $f_{2}$ променеву поверхню $\sigma \supset A_{i}, P_{i}$ як неперервну множину проекціюючих променів $\{\mathrm{s}\}\left(\mathrm{s}_{\mathrm{i}} \supset A_{i} ; P_{i}\right)$, що відповідають миттєвим положенням точок $A$ і $P$. Для довільної точки $s(x, y, z) \in \sigma$, що лежить на промені $s_{i} \subset A_{i}, P_{i}$ в момент часу $t$ маємо такі відношення:
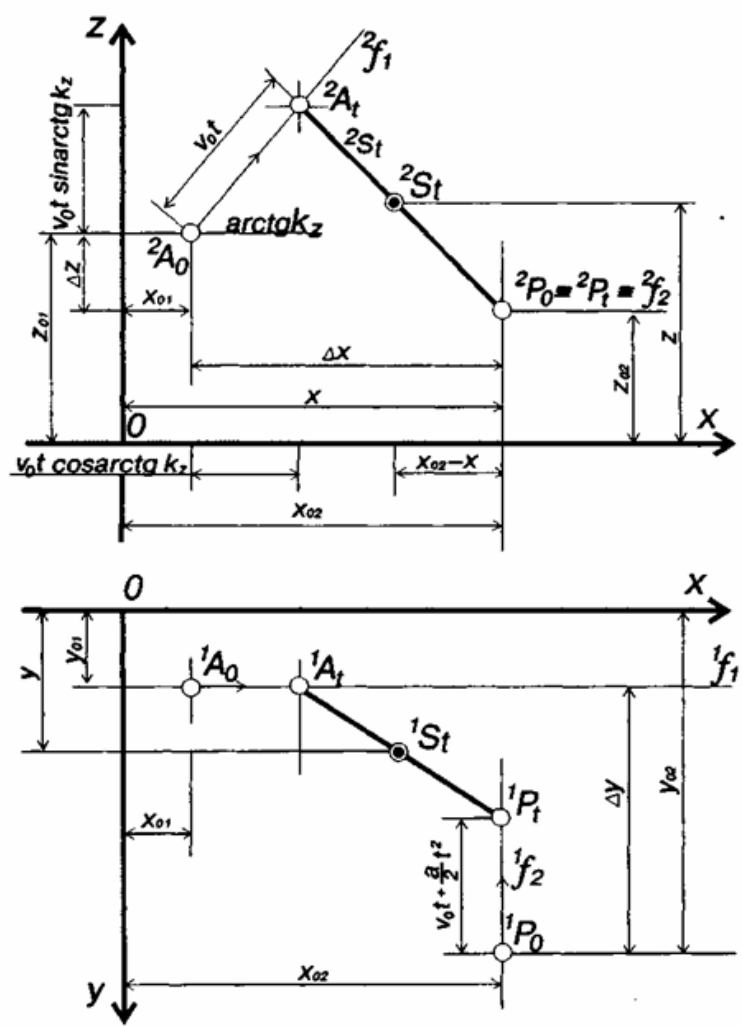

Рис. 2. Грамографічні відображення проекцій рухомих об'єкту (точка $A$ ) та центру проеціювання (точка $P_{0}$ ) на епюрі Монжа

$$
\begin{aligned}
& \frac{\Delta y-\left(v_{o} \cdot t+\frac{a \cdot t^{2}}{2}\right)}{\Delta x+v_{o} \cdot t \cdot \cos \operatorname{arctg} k_{z}}=\frac{y-y_{01}}{x-x_{01}+v_{o} \cdot t \cdot \cos \operatorname{arctg} k_{z}} \\
& \frac{\Delta z-v_{o} \cdot t \cdot \operatorname{sinarctg} \mathrm{k}_{\mathrm{z}}}{\Delta \mathrm{x}-\mathrm{v}_{\mathrm{o}} \cdot t \cdot \cos \operatorname{arctg}_{z}}=\frac{z-z_{02}}{z_{02}-x} \\
& \left(\Delta x=\left|x_{02}-x_{01}\right|, \Delta y=\left|y_{02}-y_{01}\right|,=\left|z_{02}-z_{01}\right|\right) \text {. }
\end{aligned}
$$

$$
\begin{aligned}
& \text { Після підстановки значення } \\
& t=\varphi(x, z)=\frac{\Delta z\left(x_{02}-x\right)-\Delta x\left(z-z_{02}\right)}{v_{o}\left[\left(z-z_{02}\right) \cdot \cos \operatorname{arctg} k_{z}+\left(x_{02}-\sin \operatorname{arctg} k_{z}\right)\right]}
\end{aligned}
$$

3 (1) отримуємо рівняння

$$
\begin{aligned}
& \left.\left.\Delta y-\left(v_{o} \cdot \varphi(x, z)+\frac{a}{2}(x, z)\right)^{2}\right)\right] \cdot\left(x-x_{01}+v_{o} \cdot \varphi(x, z) \cdot \cos \operatorname{arctg} k_{z}\right)- \\
& -\left(\Delta x+v_{o} \cdot \varphi(x, z) \cdot \cos \operatorname{arctg} k_{z}\right) \cdot\left(y-y_{01}\right)=0,
\end{aligned}
$$

що визначає поверхню третього порядку.

Якщо прообраз $A$ і центр проекціювання $P$ здійснюють рівномірний рух по прямим, відповідно зі швидкостями $v_{1}$ i $v_{2}$, то поверхня є квадрикою (однопорожнинний гіперболоїд або, в граничному випадку - гіперболічний параболоїд), тоді рівняння (1) набуває такого вигляду

$$
\begin{aligned}
& \left(\Delta y-v_{2} \cdot \varphi(x, z)\right) \cdot\left(x-x_{01}+v_{1} \cdot \varphi(x, z) \cdot \cos \operatorname{arctg}_{z}\right)- \\
& -\left(\Delta x+v_{1} \cdot \varphi(x, z) \cdot \cos \operatorname{arctg} k_{z}\right) \cdot\left(y-y_{01}\right)=0,
\end{aligned}
$$

де

$$
\varphi(x, z)=\frac{\Delta x \cdot\left(z-z_{02}\right)-\Delta z \cdot\left(x_{02}-x\right)}{v_{1} \cdot\left[\left(z-z_{02}\right) \cdot \cos \operatorname{arctg} k_{z}-\left(x_{02}-x\right) \cdot \sin \operatorname{arctg} k_{z}\right.} .
$$

В загальному випадку, коли шлях, що проходить $A$ або $P$ за час $t$, рівний $v_{0} \cdot t+\frac{a}{2} \cdot t^{n}$, поверхня має порядок $n+1$. Тепер введемо до розгляду площину проекцій $\pi$ з фіксованою в ній координатною системою $\eta \varsigma$.

Задамо початкове положення $A_{0}\left(x_{01}, y_{01}, z_{01}\right), P_{0}\left(x_{02}, y_{02}, z_{02}\right)$ і $\pi_{0}(x=o, \eta=y, \varsigma=z)$ елементів відображення і прямолінійні траєкторії

$$
\begin{aligned}
& f_{1}\left(y=k_{1 v} \cdot x+b_{1 v} z=k_{1 /} \cdot x+b_{1 /}\right), \\
& f_{2}\left(y=k_{2 v} \cdot x+b_{2 v} z=k_{2 /} \cdot x+b_{2 /}\right),
\end{aligned}
$$

Відповідно до точок $A$ і $P$. Приймемо також, що в процесі руху площини $\pi$ вісь $x$ залишається ії напрямним вектором.

Нехай елементи відображення починають одночасний рух: прообраз $A$ і площина $\pi$-рівномірний зі швидкістю $v_{0}$, а центр $P$ - рівномірний $з$ початковою швидкістю $v_{0}$ та прискоренням $a$. Тоді в кожний момент часу $t_{l}$ проекція $f_{1}^{\prime}$ прямої $f_{l}$ на площину $\pi$ в положенні $\pi_{1}\left(x=v_{0} \cdot t_{1}\right)$, що відповідає цьому моменту часу, є перетином променевої поверхні 3 площиною $\pi$.

Параметричні рівняння $y=y(t), z=z(t)$ нескінчених множин вторинних проекцій ${ }^{1} A^{\prime},{ }_{1} A_{2}^{\prime} \ldots ;{ }^{2} A_{1}^{\prime},{ }^{2} A_{2}^{\prime} \ldots$; (перепроеккційованих з рухомої площини $\pi$ на нерухомі площини проекцій $x y$ і $x z$ ) точки $A$ в іiї послідовних положеннях на $f_{l}$ являють собою параболічні гілки третього порядку типу

$$
y=d_{1} \cdot x^{3}+d_{2} \cdot x^{2}+d_{3} \cdot x+d_{4}
$$

за класифікацією Ньютона, а саме:

$\left(y_{02}-I_{2}-y\right) \cdot\left(x_{01}-m_{1}-v_{0} \cdot t\right)=\left(x_{02}-m_{2}-v_{0} \cdot t\right) \cdot\left(y_{01}+I_{1}-y\right)$, 
$\left(z-z_{02}-n_{2}\right) \cdot\left(\Delta x+m_{1}-m_{2}\right)=\left(x_{02}-m_{2}-v_{0} \cdot t\right) \cdot\left(\Delta z-n_{1}-n_{2}\right)$,

де

$$
\Delta x=\left|x_{1}-x_{2}\right| ; \Delta z=\left|z_{1}-z_{2}\right|
$$

$m_{1}=v_{0} \cdot t \cdot \cos \gamma_{1} \cdot \cos \beta_{1}: m_{2}=\left(v_{0} \cdot t+\frac{a \cdot t^{2}}{2}\right) \cdot \cos \gamma_{2} \cdot \cos \beta_{2}$

де

$n_{1}=v_{0} \cdot t \cdot \cos \gamma_{1} \cdot \sin \beta_{1}: n_{2}=\left(v_{0} \cdot t+\frac{a \cdot t^{2}}{2}\right) \cdot \cos \gamma_{2} \cdot \operatorname{tg} \alpha_{2} \cdot \cos \beta_{2} ;$

$I_{1}=v_{0} \cdot t \cdot \cos \gamma_{1} \cdot \operatorname{tg} \alpha_{1} \cdot \cos \beta_{1}: I_{2}=\left(v_{0} \cdot t+\frac{a \cdot t^{2}}{2}\right) \cdot \cos \gamma_{2} \cdot \operatorname{tg} \alpha_{2} \cdot \cos \beta_{2}$

Тут

$\alpha_{1}=\operatorname{arctg} k_{1 v} ; \beta_{1}=\operatorname{arctg} k_{1 /} ; \gamma_{1}=\operatorname{arctg}\left(\operatorname{tg} \alpha_{1} \cdot \cos \beta_{1}\right) ; j=1,2$

При рівномірному русі всіх елементів відображення рівняння (5) і (6) визначають квадратичні параболи.

В гранично спеціалізованому положенні траєкторії прообразу $A_{0}\left(x_{01}, O_{1} z_{01}\right)$ і центра $P_{0}\left(x_{02}, y_{02}, o\right)$

$$
f_{1}\left(x=x_{1}, y=0\right), f_{2}\left(x=x_{2}, z=0\right)
$$

i рівномірному русі всіх елементів з однаковою одиничною швидкістю $(v=1)$ рівняння $y=y(t)$ і $z=z(t)$ мають вигляд

$$
\begin{gathered}
y=\frac{1}{\Delta x} \cdot\left(y_{2}-t\right) \cdot\left(x_{1}-t\right), \\
z=\frac{1}{\Delta x} \cdot\left(z_{2}-t\right) \cdot\left(x_{1}-t\right),
\end{gathered}
$$

або в канонічній формі

$$
\left[t-\frac{1}{2} \cdot\left(x_{1}+y_{2}\right)\right]^{2}=\Delta x \cdot\left[y+\frac{1}{\Delta x} \cdot\left(\frac{1}{4} \cdot\left(x_{1}+y_{2}\right)^{2}-x_{1} \cdot y_{2}\right)\right],
$$

$$
\left[t-\frac{1}{2} \cdot\left(x_{1}+z_{1}\right)\right]^{2}=\Delta x \cdot\left[z+\frac{1}{\Delta x} \cdot\left(\frac{1}{4} \cdot\left(x_{1}+z_{1}\right)^{2}-x_{1} \cdot z_{1}\right)\right]
$$

Таким чином, в цьому випадку проекції траєкторії прообразу $A$ - конгруентні квадратичні параболи (9), (10) з параметром $\frac{1}{2} \cdot \Delta x$.

Ілюстрацією грамографічного відображення $\epsilon$ епюр (рис. 2). На епюрі представлені первинні (на рухомій площині $\pi$ ) $f_{1}^{\prime}$ і вторинні (перепроекційовані 3 $\pi$ на нерухомі координатні площини $x y, x z, y z$ ) ${ }^{1} f_{1}^{\prime},{ }^{2} f_{1}^{\prime},{ }^{3} f_{1}^{\prime}$ проекції прямолінійної траєкторії $f_{l}$ прообразу (точки) $A$ в $\gamma \gamma \gamma$ відображенні.

$A_{0}, P_{0}, \pi_{0}$ - початкові положення прообразу $A$, центру проекціювання $P$, площини проекцій $\pi$. $f_{2}-$ траєкторія руху $P, f_{3}-$ напрямний вектор руху площини $\pi$. Всі рухи рівномірні, швидкість всіх елементів проекціювання рівні, рух одночасний. Такий режим руху названий канонічним. Як було показано раніше, всі проекції траекторії $\mathrm{f}_{1}$ - квадратичні параболи.

\section{Результати та їх обговорення}

Окрім вирішення прямої задачі кінематичного проеціювання, яка переважно полягає у побудові проекції траєкторії рух об'єкта проеціювання, цей різновид проеціювання надає і можливість рішення зворотної задачі, а саме за відомою проекцією траєкторії руху об'єкта пошук його координат. Зворотна (локаційна) задача кінематичного проекційного відображення, як зазначено вище, полягає у визначенні положення прообразу $A$ за його образом $A^{\prime}$, тобто

$$
F^{1}: A^{\prime} \subset \pi \rightarrow A \subset \Pi
$$

в довільний момент часу $t$ (рис. 3 ).

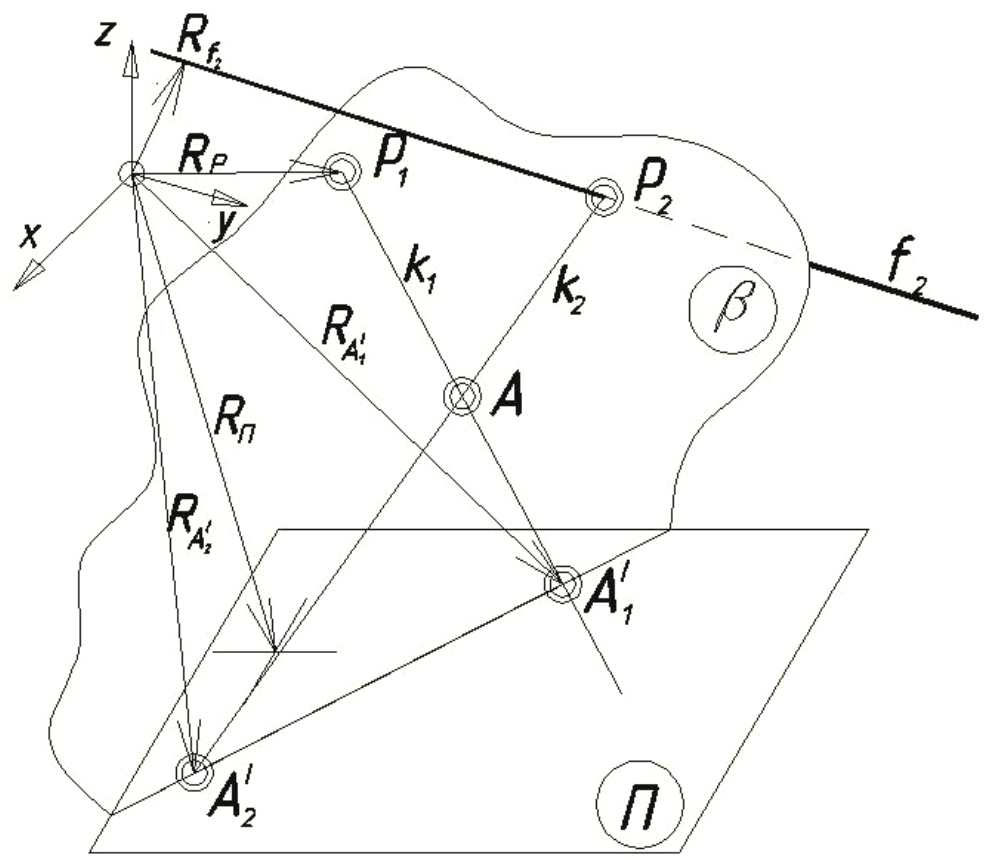

Рис. 3. Принципова схема грамографічного відображення рішення “оберненої задачі” на пошук об’єкта при кінематичному проеціюванні 
Очевидно, що для ін'єктивності локації необхідно мати два компоненти $\mathrm{A}_{1}^{\prime}, \mathrm{A}_{2}{ }_{2}$ образу $\mathrm{A}^{\prime}$, отриманих проекціюванням прообразу $\mathrm{A}$ із двох центрів $\mathrm{P}_{1}, \mathrm{P}_{2}$ (лінійні відображення) (Kalynovska et al., 1994), або із двох конгруенцій (нелінійні відображення) (Kalynovska et al., 1994)

$$
\begin{gathered}
F^{1}: A_{1}^{\prime}, A_{2}^{\prime} \frac{P_{i}, P_{2}}{(\ldots)} \rightarrow A \\
F^{1}: A_{1}^{\prime}, A_{2}^{\prime} \frac{S_{1}^{2}\left(\varphi_{1_{1}}, \varphi_{1_{2}}\right), S_{2}^{2}\left(\varphi_{2}, \varphi_{2_{2}}\right)}{(\ldots)} \rightarrow A
\end{gathered}
$$

Строго графічне (циркульне) розв'язання задачі можливе в однорідному просторі, тому що реалізується в кінцевому результаті - як перетин двох прямолінійних проекціюючих променів $\mathrm{s}_{1}{ }_{1} \mathrm{i} \mathrm{s}^{0}{ }_{2}\left(\mathrm{~A}=\mathrm{s}^{0}{ }_{1} \cap \mathrm{s}_{2}{ }_{2}\right)$ (Kalynovska et al., 1994).

Прикладом виробничого використання кінематичного проеціювання може слугувати процес автоматизованого обробітку відповідним чином облаштованих сільськогосподарських угідь. Його принципова схема відображена на рис. 4. До автоматизованого комплексу обробки земельної ділянки тут входять оснащений приймальною антеною та системою дистанційного керування виконавчий агрегат із функціональним навісним обладнання для обробки землі чи сільськогосподарських культур. Наприклад, трактор з причіпним плугом, боронами чи косаркою, комбайн, моторизований обприскувач тощо. Переміщеннями моторизованого землеобробного механізму та його виконавчими агрегатами дистанційно керують із віддаленого пункту дистанційного керування, оснащеного комп'ютерною технікою 3 відповідним програмним забезпеченням, монітором для відслідковування за переміщеннями землеобробної техніки та радіолокаційною станцією (РЛС) для прийняття та передачі радіосигналів відслідковування та корегування роботами механізмів і агрегатів землеобробної техніки.
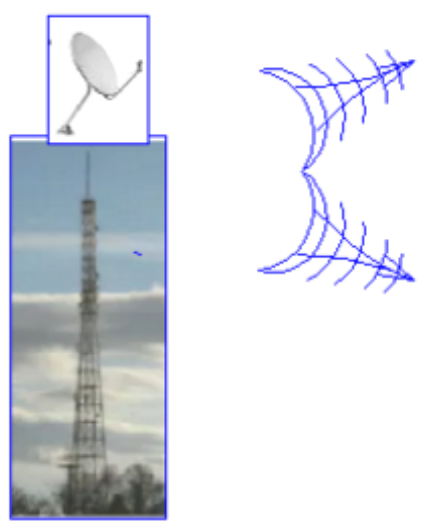

Padiobexa

\section{Безпіпотний літальний anapam (DpoH)}
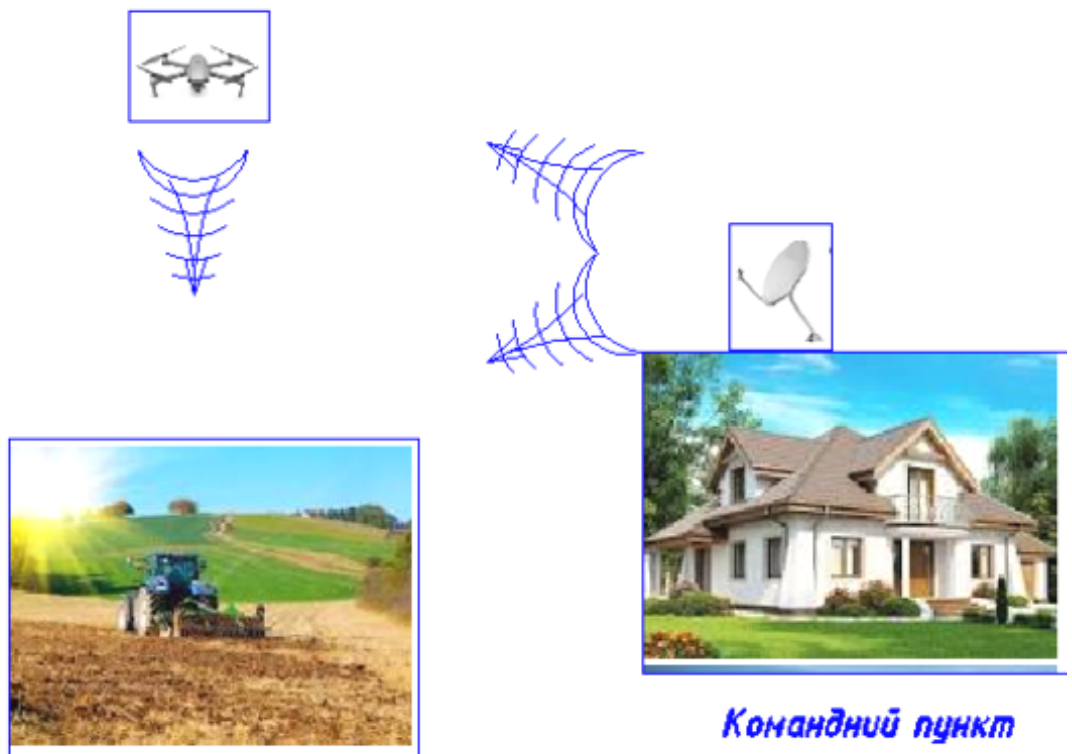

KомaHdHÜ̈ nунKm

\section{Padioкерований землеобробниё azpezam}

Рис. 4. Спеціалізований сільськогосподарський комплекс автоматизованого керування землеобробною технікою із використанням пульта керування

Для усунення спотворення нерівностями земельної ділянки радіосигналів на ділянці додатково можуть облаштовувати допоміжну радіовежу із приймальнопередавальною антеною. За відсутності радіовежі функції контролюючої приймально-передавальної ланки можуть бути покладеними на відповідно оснащений безпілотний літальний апарат (БПЛА). Літальний апарат, наприклад дрон, літаючи чи “зависаючи” над оброблюваною ділянкою, сприйматиме керівні радіосигнали від пульта керування РЛС та надсилатиме на пульт керування інформативні сигнали про місце розташування землеобробної техніки.
Дана технологічна схема землеобробки є прикладом можливості застосування принципів кінематичного проеціювання. Рухомий із певними швидкістю та прискоренням землеобробний агрегат тут є об'єктом проеціювання, відслідковуючий переміщення землеобробного агрегату літаючий БПЛА слугує у даному випадку рухомим центром проеціювання. Екран комп'ютерного монітора на пульті управління тут відіграє роль “плаского носія інформації, тобто за термінологією нарисної геометрії “картинної площини проеціювання”. Переважно тут на екрані висвітлюється траєкторія руху землеобробного агрегату та його можливі відхилення від неї. Ці відхилення під- 
даються негайному корегуванню. Дана система за потреби може відобразити в аксонометричному відтворенні також розташування та координати і землеобробного агрегата, i контролюючого БПЛА, тобто об'єкта і центра проеціювання. Однак переважно у цьому немає потреби, оскільки цілком достатньо зображення облаштованої на БПЛА чи радіовежі відеокамери.

Отже, у даному випадку, оперуючи складовими кінематичного проеціювання, тобто рухомими об’єктами проеціювання - землеобробним агрегатом, центром проеціювання - літаючим БПЛА, а також “умовно рухомою із нульовою швидкістю” площиною проеціювання, можна забезпечити зведення до мінімуму можливих помилок людини-оператора. Адже в існуючій технологічній схемі керівництво рухами та переміщеннями землеобробного агрегату здійснюється за зображеннями відеокамер в ручному режимі. I тут неминучий вплив людського чинника. Таким чином, застосування кінематичного проеціювання в технологічних схемах автоматизованого землеобробітку спроможне підвищити продуктивність та якість цього процесу завдяки усуненню можливих похибок операторів.

У даному прикладі вдосконалення автоматизованого виробництва ми мали приклад вирішення так званої “прямої задачі” кінематичного проеціювання. Ця задача передбачає пошук та побудову на пласкому носії траєкторії (проекції) просторового переміщення об'єкта проеціювання, що рухається із певними швидкостями. При цьому використовують дані про швидкість та траєкторію просторових переміщень одного центра проеціювання. В розглянутому прикладі у якості якого розглядався БПЛА.

На рис. 5 відображена, як приклад, одна із можливих у практичному застосуванні принципова схема рішення “оберненої” задачі кінематичного проеціювання. Тут відображено іiі використання для визначення просторових координат невідомого БПЛА за проекціями тракторії його просторового переміщення. Із технічних засобів для виявлення просторових координат невідомого об'єкта, наприклад, як зображено на схемі, дрона А, тут використовуть два оснащені радіопередавачами пошукові дрони № 1 та № 2. Цим пошуковим дронам у принциповій схемі відведено роль центрів проектування $\mathrm{P}_{1}$ та $\mathrm{P}_{2}$. Зв'язок із пошуковими дронами здійснюєтся через оснащену відповідною комп'ютерною технікою із належним забезпеченням наземною радіолокаційною станцією (РАC) (на рисунку не відображено). Пошук координат невідомого об'єкта здійснюєтся у такій послідовності. Спеціальною комп'ютерною програмою задають координати уявного просторового центра (точка О) системи відліку, тобто системи координат із взаємно перпендикулярними осями $\mathrm{x}, \mathrm{y}$ та z. Задавши координати трьох довільних точок, наприклад L, N, M, призначають просторове розташування “картинної пло- щини” $\alpha$, на яку проектуватимуться точки проекції траекторії руху невідомого об'єкта. Подається команда на пошукові дрони № 1 та № 2, що як центри проектування із незначними інтервалами в часі спрямовують проектуючі промені на невідомий літальний апарат (дрон А у даному випадку). Комп'ютер прораховує точки перетину проектуючих променів $\mathrm{P}_{1} \mathrm{~A}_{2}$ та $\mathrm{P}_{2} \mathrm{~A}_{1}$ iз “картинною площино" $\alpha$, тобто точки $\mathrm{A}_{1}^{\prime} \mathrm{i}$ $\mathrm{A}_{2}^{\prime}$, формує уявну січну площину $\beta$, що задана двома проектучими променями $\mathrm{P}_{1} \mathrm{~A}_{2}=\mathrm{P}_{1} \mathrm{~B}$ та $\mathrm{P}_{2} \mathrm{~A}_{1}=\mathrm{P}_{2} \mathrm{C}$ як площини, заданої пересічними прямими. Комп'ютерна програма прораховує розташування лінії k як лінії, що являє собою лінію перетину між собою двох відомих площин $\alpha$ та $\beta$ і проходить через вже відомі координати точок $\mathrm{A}_{1}^{\prime}$ i $\mathrm{A}_{2}^{\prime}$.

Через незначний проміжок часу $\Delta \mathrm{t}$ всі три рухомі iз різними швидкостями дрони змінять в просторі своє розташування. Повторяться вищеописані етапи кінематичного проеціювання, і за сигналами відбитих від розшукуваного невідомого об'єкта радіохвиль чи лазерного променя комп'ютер перерахує і відобразить на екрані зміни координат дронів пошукувачів, що $є$ центрами проеціювання, та зміни координат їх проекцій на “картинній плошині”. При цьому (у випадку потреби) сформується і відобразиться нова лінія $l$ перетину сформованої $\gamma$ новими проектуючими променями, площини б із “картинною площино”, тобто $l=\sigma \cap \alpha$. Своєю чергою перетин на “картинній площині” ліній $l$ та k між собою сформує точку $\mathrm{K}_{1}=l \cap \mathrm{k}$, яка належить проекції траєкторії просторових переміщень невідомого об'єкта (дрона А) на “картинній площині”.

Знову все повториться через проміжок часу $\Delta \mathrm{t}$. На “картинній площині” відобразиться чергова лінія $\mathrm{n}=\gamma$ $\bigcap \alpha$ як лінія перетину чергової площини $\gamma=\mathrm{P}_{1} \mathrm{~A}_{3}{ }_{3} \cap$ $\mathrm{P}_{2} \mathrm{~A}_{3}$, сформованої новим перетином чергової пари проектуючих променів. Перетин ції лінії $n$ із попередньо побудованою лінію $l$ надають нову точку $\mathrm{K}_{02}^{\prime}$, тобто $\mathrm{K}_{02}^{\prime}=n \cap l$. А почергове з'єднання точок $\mathrm{K}_{0}^{\prime}, \mathrm{K}_{01}^{\prime}$, $\mathrm{K}_{02}^{\prime} \ldots \mathrm{K}_{0 \text { п }}^{\prime}$ і сформує шукану проекцію траєкторії просторових переміщень невідомого літаючого об'єкта, тобто дрона А.

Оскілки переважно літаючі об'єкти переміщаються у тривимірному просторі із певними значеннями висоти по координаті Z, то одночасно із заданням горизонтально розміщеної “картинної площини” $\alpha$ доречно задавати бодай ще одну перпендикулярну до $\alpha$ “картинну площину”, наприклад $\omega$. I одночасно аналогічно будувати і на цій “картинній площині" проекцію траєкторії руху об’єкта А.

Тоді, провівши із відповідних точок горизонтальної та перпендикулярної їй допоміжної площини $\omega$ лінії зв’язку, комп'ютерна програма розшукає аксонометричну проекцію просторової траєкторії руху літаючого об'єкта (дрона А) та координати будь-якої точки цієї траєкторії руху. Це і є кінцевим результатом рішення даної задачі. 


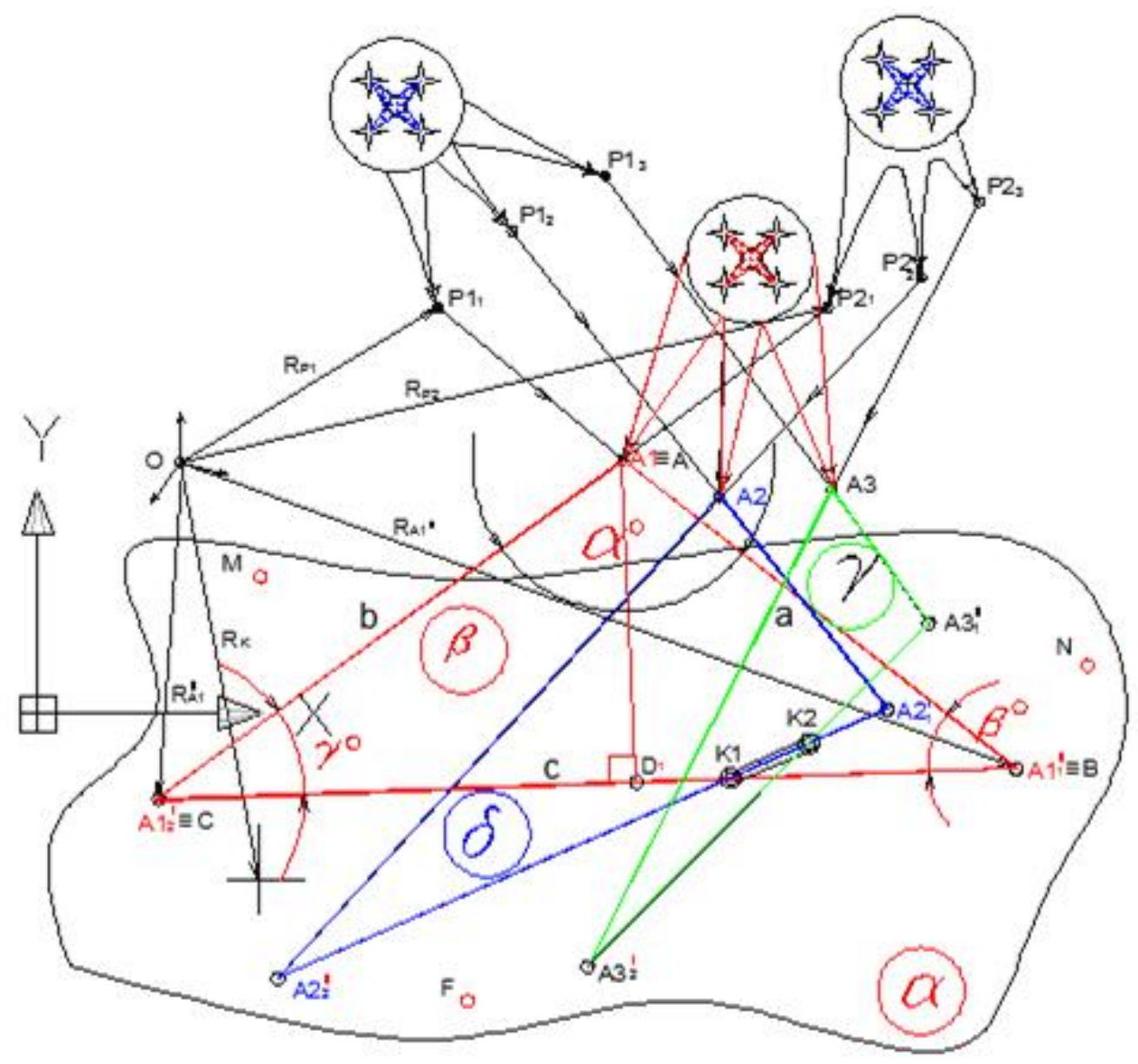

Рис. 5. Визначення координат та траєкторії руху невідомого об'єкта рішенням “оберненої задачі” кінематичного проеціювання

Дана схеми пошуку координат та траєкторій невідомих рухомих об'єктів є доволі універсальною і може застосовуватися як для ї пошуку в повітряному просторі, так і для визначення їхнього місця розташування на суші, на воді та у товщі води. Порівняно 3 існуючими методами виявлення та знешкодження ворожих БПЛА-розвідників, які грунтуються на пошуку і виявленню цих літальних апаратів як "матеріального тіла певної маси", метод кінематичного проеціювання математично прораховує координати об’єкту як точки перетину проектуючих променів. А це і простіше, і на порядок точніше. Отже, перевагами кінематичного проеціювання $\epsilon$ :

- спроможність визначення та відображення об'єкта на екрані комп'ютера не тільки в плоскому відображенні, а і з врахуванням його просторової координати по висоті, наприклад, віддаленості від горизонту. Це надає можливість спостережень за переміщеннями об'єкта не лише у часовому інтервалі, а й у тривимірному просторі.

\section{Висновки}

1. Стрімкий розвиток у сьогоденні комп'ютерної техніки та їі програмного забезпечення надав можливість широкого практичного застосування кінематичного проеціювання, яке дозволяс відображати в прое- кційному зв'язку рухомі із взаємонезалежними швидкостями в просторі та часі класичні складові проеціювання, а саме: його центр, об'єкт, проектуючий промінь та проекцію на "картинну площину".

2. Рішення так званої “прямої задачі" кінематичного проеціювання передбачає можливість побудови на “картинній площині" проекцій траєкторії руху об’єкта проеціювання як у площинному, так і в аксонометричному відображенні. У практичному застосуванні це надає можливість завдання, відслідковування та корегування траєкторій руху, наприклад, транспортних засобів, механізованих землеобробних засобів автоматизованих землеобробних комплексів тощо.

3. Рішення так званої "оберненої задачі” кінематичного проеціювання передбачає можливість пошуку координат руху та просторового місцерозташування об'єкта проеціювання при відомій траєкторії його руху. Для цього використовують два рухомих незалежних центри проеціювання, перетин проектуючих променів яких відображає координати підлягаючого ідентифікації невідомого об'єкта. Застосування рішень “оберненої задачі" кінематичного проеціювання буде ефективним для пошуку в повітряному просторі літальних апаратів та нерозпізнаних об'єктів, а також для виявлення у товщі води рухомих плавучих засобів, зокрема торпед, підводних човнів, підводних гідроциклів тощо. 
Перспективи подальших досліджень. В подальшому планується використання описаних вище методів для виявлення координат БПЛА. Суть проблеми полягає в тому, що через незначну масу цих розвідувальних апаратів (дронів) їх пошук у просторі як “матеріальної” точки або за шумовими ефектами працюючого двигуна вкрай ускладнений. У результаті спрямовані на ураження розвідувальних БПЛА засоби ПВО, не володіючи точними координатами розташування ворожих розвідувальних БПЛА, малоефективні. Для цього необхідні точні координати розташування об'єкта в просторі. Саме це і спроможне забезпечити кінематичне проеціювання.

\section{References}

Bespalov, A., Svidrak, I., \& Boiko, O. (2020). Improving the performance of vibration feeders with an electromagnetic vibration drive and a combined vibration system. Scientific Messenger of LNU of Veterinary Medicine and Biotechnologies. Series: Food Technologies, 22(93), 26-30. doi: 10.32718/nvlvet-f9305.

Kalinovskaja, O. P., Glogovskij, V. V., \& Pul'kevich, I. G. (1994). K probleme edinoj teorii proekcionnyh otob-razhenij. Prikl. geom. i inzh. graf., 57, 45-50 (in Russian).

Kalynovska, O. P., Hlohovskyi, V. V., \& Pulkevych, I. H. (1994). Neliniini operatory kinematychnykh proektsiinykh vidobrazhen. Pr. Lv. Mizh nar. nauk.-metod. konf. $\mathrm{z}$ heometrychnoho modeliuvannia, inzh. ta komp. hraf. L., 36 (in Ukrainian).

Kalynovska, O. P., Hlohovskyi, V. V., Pulkevych, I. H. (1994). Lokatsiini zadachi kinematychnykh proektsiinykh vi-dobrazhen. Pr. Lv. Mizhnar. nauk.-metod. konf. $\mathrm{z}$ heometrychnoho modeliuvannia, inzh. ta komp. hraf. L., 37 (in Ukrainian).

Kul'minskij, O. K., \& Nikolaevskij, G. K. (1971). Kinoaksonometrija kak metod ob\#emnograficheskogo mode-lirovanija. Prikl. geometrija i inzh. grafika, 12, 136-138 (in Russian).

Lihachev, L. N. (1975). Kinoperspektiva. M.: "Vysshaja shkola" (in Russian).

Mihajlenko, V. E., Obuhova, V. S., \& Podgornyj, A. L. (1972). Formoobrazovanie obolochek v arhitekture. K. Budivel'nik (in Russian).

Pilipaka, S. F. (1991). Primenenie metodov nachertatel'noj geometrii dlja nahozhdenija skorostej proizvol'nyh tochek tverdogo tela, sovershajushhego prostranstvennye dvizhenija. Prikl. geometrija i inzh. grafika. 51, 62-64 (in Russian).

Pulkevych, I. H. (1994). Liniini operatory kinematychnykh proektsiinykh vidobrazhen. Pr. Lviv. Mizh nar. nauk-metod. konf. $\mathrm{z}$ heometrychnoho modeliuvannia, inzh. ta komp. hraf. L., 35 (in Ukrainian).

Rynin, N. A. (1936). Kinoperspektiva. M.: Kinofotoizdat (in Russian).

Shevchyk, A., Svidrak, I., Bilyk, N., \& Poberezhska, I. (2021). Crystallomorphological and physical properties of apatite from carbonatites. Scientific Messenger of LNU of Veterinary Medicine and Biotechnologies. Series: Food Technologies, 23(95), 25-32. doi: 10.32718/nvlvet-f9505.

Tkach, D. I. (1968). Nekotorye voprosy kinoperspektivy i postroenie arhitekturnyh perspektiv. Izd. vyssh. uch. zaved., ser. "Stoitel'stvo i arhitektura", Novosibirsk (in Russian). 